\title{
https://doi.org/10.5817/OS2020-3-5
}

\section{Maska mima}

Jsou lidé, které osud obchvátí hned na začátku. Patří k nim také Piotr Myszyński (1960) z Białé u Prudniku. Již v dětství mu učarovala pantomima. Proto dělal všechno, aby byl přijat do Wrocławského Teatru Pantomimy, jemuž vévodil slovutný Henryk Tomaszewski. Svět se Piotrovi zhroutil, když mu vypovědělo tělo, zbortilo se a on zůstal na vozíčku. Zůstalo mu pouze pero a barvy, poezie a malířství. Silou své vůle však rovněž pantomima, kterou při nejrůznějších př́iležitostech předvádí na svém vozítku. Sám jsem byl účasten jednoho takového představení v červnu 2013 při básnickém plenéru ve Wieszczyně u Prudniku. Bylo to zajímavé a zároveň dotírající. Stále jsem nebyl schopen si odmyslet ten vozík.

Svému učiteli se stále obdivuje. Když roku 2001 zemřel, připsal mu ve své třetí sbírce nazvané Nebeská propast (Niebiańska czeluść) celý oddíl. K jeho skonu se váže báseň Moje mekka (Moja Mekka), v níž jsou mimo jiné tyto verše:

\section{Drobna skrzypaczka w czarnych pończochach gra sonaty Jana Sebastiana Bacha \\ na śmierć wielkiego mima \\ tancerza Henryka Tomaszewskiego \\ Malá houslistka $v$ černých punčochách \\ hraje sonáty Johanna Sebastiana Bacha \\ na smrt velkého mima \\ tanečníka Henryka Tomaszewského}

U Piotra Myszyńského jsem byl bezděčným svědkem obou lidských krajností. Ta negativní se týká nemoci. Před několika roky jsme jej spolu s básníkem (a jeho editorem) Wojtkem Ossolińskim navštívili v prudnické nemocnici. Ležel spolu s několika dalšími pacienty v podlouhlém pokoji jako učiněný lazar. Bez zájmu a bez naděje. Díkybohu, že byl se mnou Wojciech, jenž bizarně tísnivou situaci překlenul svou upř́mnou a povzbudivou hovorností. Já za celou tu dobu jsem nebyl schopen cokoliv říci. Bylo to vskutku bolavé. A opačnou situaci, tu pozitivní, jsem zažil krátce před jeho pantomimickým vystoupením ve zmíněné Wieszczyně. Svůj chystaný program, jak podotkl, bude bez hudebního doprovodu, zalitoval toho on i já. A nato následoval vřelý hold Händelovi, Georgu Friedrichovi, jehož muzika obvykle doprovází jeho vystoupení. Obdiv k mistrovi byl pronášen nejen slovy, ale jako mim jeho velikost doprovázel také gesty rukou. Plavaly mezi námi a Piotr si mezitím zahrával s dvojicí slov Händel a Handel. Vše nakonec komentoval v anglickém jazyce. To proto, že rodák 
z Halle skončil nakonec v Anglii? Není jistě náhodou, že tvůrce Mesiáše se objevuje rovněž v Nebeské propasti, konkrétně v básni Zkouška (Proba).

Myszyńskému vedle torzaické pantomimy zůstalo tedy malování a básnění. Svoji Nebeskou propast vydal Piotr spolu s matčinými básněmi pod titulem Pod věží (Pod Wieżą). Kniha je doprovázena reprodukcemi jeho olejů s krajinnou tematikou. Obdobně je tomu v jeho $\mathrm{v}$ pořadí druhé sbírce s provokujícím názvem Tančím (Tańczę), kde se jako ilustrace objevují jeho grafiky. Obojí, zejména však oleje se souboru Pod věží, má expresionistický ráz, ryze a rozmáchle expresionistický. Souvisí to nepochybně s jeho fyzickými omezeními. Je však docela možné, že zde zasahuje (proniká) i něco z jeho slezanství, jež má částečně také německé kořeny.

$\mathrm{O}$ autorově vlastní mentalitě a vzdornosti pak svědčí nejedna báseň sbírky Tančím, kupř. báseň Dům (Dom), jež končí těmito verši:

$\begin{array}{ll}\text { Bałagan i rozpacz } & \text { Neporádek a zoufalství } \\ \text { Troszkę czasu } & \text { Trocha času } \\ \text { Cisza }=\text { Zima = ni ma } & \text { Ticho = Zima = nemá } \\ \text { Mima } & \text { Mima } \\ \text { Tylko niemy gest } & \text { Pouze němé gesto } \\ \text { Poruszenia przyborów } & \text { Vzedmutí stoupající vody } \\ \text { Siedzę w ogromnym fotelu } & \\ \text { Sklerosis mól tip ex } & \text { Sedím ve velké lenošce } \\ & \text { Sklerosis mol tip ex }\end{array}$

Explicit básně je přitom příznačný, nebot' básník se v něm povznáší nad svou omezující a atakující sklerosis multiplex.

Piotrova matka Anna, podílející se na souboru Pod věží veršovanými texty, patří k lidovým písmákům slezského regionu.

František Všetička

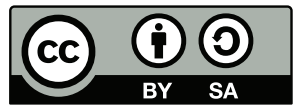

Toto dílo Ize užít v souladu s licenčními podmínkami Creative Commons BY-SA 4.0 International (<https:// creativecommons.org/licenses/by-sa/4.0/legalcode>). Uvedené se nevztahuje na díla či prvky (např. obrazovou či fotografickou dokumentaci), které jsou v díle užity na základě smluvní licence nebo výjimky či omezení príslušných práv.

\section{Štvrtá vedecko-praktická konferencia rusistov}

Dňa 8. 11. 2019 sa v rámci Mezinárodného knižného veltrhu „Bibliotéka“ v Bratislave z iniciatívy Velvyslanectva Ruskej federácie v Slovenskej republike a za podpory ruskej agentúry Rospečat', Ruského centra vedy a kultúry v Bratislave, Moskovskej 